\title{
Politics of Language Choice in African Education: The Case of Kenya and Malawi*
}

\author{
Sam Mchombo \\ University of California, Berkeley, USA
}

In August 2015 the government of South Africa issued Circular S10 of 2015, to inform education authorities that Mandarin would be taught in the schools beginning January 2016. Immediately, the South African Democratic Teachers' Union (Sadtu) expressed stiff opposition to it, rejecting it as constituting a "new form of colonization". The notification informed national and provincial education authorities that Mandarin would be incrementally implemented in schools such that "Grades 4-9 and 10 will be implemented in January 2016, followed by grade 11 in 2017 and grade 12 in 2018" (Nkosi, 2015). Part of the justification for the introduction of Mandarin is that China is South Africa's biggest trading partner; as such, it is important for the children of South Africa to "become proficient in the Confucius language and develop a good understanding of Chinese culture" (Nkosi, 2015). There was nothing said about China's reciprocation through changes to the language curriculum of China's educational system. Sadtu's reaction conforms to the interrogation of the use of language and education as the arena of power politics, exemplified here by the asymmetric power relations between the two countries. This feeds into the realities of African education that, largely, remains shackled through its content and languages of instruction to foreign knowledge systems, reinforced through globalization, science and technology. For instance, with regard to language of instruction the Malawi Government issued the Education Act of 2012 that decreed that English would be studied and used as medium of instruction from grade 1. Language-in-education policies of other African countries differ minimally from that of Malawi. With focus on Kenya and Malawi the paper will examine the politics of language and curricula in African education.

Keywords: colonialism, African education, national language, language in education, conceptual and linguistic incarceration, decolonization, multilingualism

\footnotetext{
* Paper was presented in the panel on Transnational Dimensions of Language Politics at the $24^{\text {th }}$ World Congress of the International Political Science Association, Poznan, Poland 23-28 July 2016. I am indebted to Zehlia Babaci-Wilhite, Herman Batibo, Hatem A. Bazian, Monica Kahumburu, Edrinnie Kayambazinthu, Langa Khumalo, David Kyeu, Patricia Pui Ki Kwok, Francis Moto, Louisa Chinyavu Mwenda, Vikuosa Nienu, Maureen Ommeh, and Amelia Hopkins Phillips for critical comments on earlier versions of the paper. None of them necessarily endorses the views expressed here nor is any one of them responsible for any errors in the paper. Those are to be blamed on me. I am grateful to Franklyn Odhiambo for assistance with proofreading and formatting. In American Canyon, California, Flora Suya came along at a critical juncture to provide much needed assistance and emotional support. Saúl Garcia worked diligently with me to ensure that I observe the fundamental right of my physique to have happy numbers. Erick Nelson, subjected to comparable requirements, was a source of inspiration and encouragement. Collin Domingo, Justin Jafari, and Nicolas Rapacon were supportive through encouraging me to adhere to the schedule. Thanks guys. Finally, at the Junction Brewery and Grill, "where family and friends meet", Courtney Collins, José Flores, Savannah Garcia, Carole Lonzanida, Scott Turnnidge, and Vilma Francis Lanalla Illimi Wakin have made for happy times. Thank you guys for always making me feel that I am among family and friends.

Sam Mchombo, Ph.D., Associate Professor, Department of African American Studies, University of California, Berkeley.
} 


\section{Race and the Colonial Experience}

Stelios Michalopoulos and Elias Papaioannou open their 2013 paper "The Long-Run Effects of the Scramble for Africa" with the blunt observation that "The predominant explanations on the deep roots of contemporary African underdevelopment are centered around the influence of Europeans during the colonial period... but also in the centuries before colonization when close to 20 million slaves were exported from Africa..." Undeniably, the effects of slavery and colonialism continue to impact the political and economic lives of people of African descent both on the African continent and in the diaspora. Political and economic domination of the Europeans over the Africans destroyed traditional institutions and relationships that protected people and constrained power, imposed authoritarian governments, and, effectively eliminated democratic practice (Wiseman, 1990). It reduced individuals' rights while simultaneously creating a very high degree of social stratification and the maintenance and intensification of parochial tribal identities (Silk, 1990). The destruction of indigenous institutions was accompanied by the introduction of western systems of government, western knowledge systems, religious beliefs, cultural values, and languages. The most effective institution in achieving such domination and control, and the forced acceptance of the superiority of European values, was "formal education". African education became the vehicle for the accomplishment of the colonial agenda, couched in the propagandist view of comprising a civilizing mission. Cammack, Pool and Tordoff (1988) state clearly that "French political officers believed in France's civilizing mission and the thrust of their assimilationist policy was to substitute French language, culture and nationality for indigenous social and cultural systems" (p. 22).

The civilizing mission was predicated upon the Europeans' construction of race and denigration or downright denial of the humanity of people of color. Omi and Winant (1994) provide insight into the challenge to Europeans' conceptions of the origins of the human species when they encountered people who looked different from them in the New World. These "natives" did not merely challenge the prevailing conceptions of the nature of humanity, but also "raised disturbing questions as to whether all could be considered in the "family" of man. Religious debates flared over the attempt to reconcile the Bible with the existence of "racially distinct" people. Arguments took place over creation itself, as theories of polygenesis questioned whether God had made only one species of humanity ("monogenesis"). Europeans wondered if the natives of the New World were indeed human beings with redeemable souls" (Omi \& Winant, 1994, p. 61). The skepticism or denial of the humanity of other races became the basis for the expropriation of political rights, the introduction of slavery and other forms of coercive labor, as well as outright extermination of those races. This was because the European conceptual framework presupposed a world-view that distinguished Europeans, children of God, human beings, etc., from "others" (Omi \& Winant, 1994, p. 61) This was not merely confined to "the new world" or Africa. In Asia, the British had a similar approach. Commenting on the impact of British presence on the culture of the people of Nagaland on the Indian subcontinent, Nienu (2015) states that "The newly arrived British had the sole intention of subjugation with a totally different religious tradition and culture - the heritages of deeply embedded western civilization and different cultural, social, political, and economic systems" (p. 93).

The civilizing mission would, conceivably, contribute towards the restoration of a modicum of humanity to the "native" who lacked knowledge, culture, values, or language. This is in keeping with the standard approach of dominant societies in that they normally deny "... the authenticity of other people's systems of 
knowledge" (Elliott, 2009, p. 285). With regard to language, Robert July (1992) points out that the descriptions of Africa by outsiders "... tended on the exotic and mysterious, often uninformed and not infrequently with pejorative connotations. Africa was the "dark continent", remote, inscrutable, primitive. Africans were said to have no language; they squeaked and jibbered" (p. 144). This had profound effect on the practice of formal education in Africa, both in terms of content and language of instruction.

\section{Content and Language in African Education}

Independence came to African states with the institutions of the colonialists firmly established. Chief among those was the educational system in the form of formal schooling. This is distinct from the general conception of education conceived of as "... imparting knowledge about the world..." (Babaci-Wilhite, 2016, p. $3)$. This education comprises training of the young to become knowledgeable and responsible citizens. It includes the transmission of cultural values, morals, kinship systems, inheritance procedures, specialized skills needed for survival, religious beliefs, legends and history of the community, customs and traditions pertaining to various aspects of life and living (including dying), rites of passages as one makes transition in life, duties and responsibilities associated with age as well as sex and gender etc. In this regard it embraces much more than is covered in formal schooling. Language facilitates the learning process, the transmission of the said traditional knowledge, and contributes to cultural identity. Language is the vehicle of expression of the knowledge of the society. This is indigenous or traditional knowledge. Every society engages in some educational practice of this kind, an educational program that is embedded in the cultural context (Nasir \& Hand, 2006; Shizha, 2012).

The expression of language in the medium of oral speech has influenced the representation and transmission of knowledge in oral form. Such transmission imposes certain requirements such as situating the performance within the cultural context, individuals' direct participation, and a focus on local issues and local development. Oral performance was central to citizenship training, the cultivation of moral values, training the young in practical skills, socialization into the cultural practices and religious beliefs, cognitive development, etc. In other words, the oral tradition has served as the main vehicle of education and of knowledge representation in many societies. African indigenous knowledge systems, as in many other societies, have been in the form of oral performance and participation in overall cultural life.

Further, traditional or indigenous knowledge tends to be largely holistic rather than compartmentalized into discrete and disparate disciplines. The education that such a tradition embodies is 'total' in that it is for survival rather than for specialization in some arcane scholarly field, despite not negating that. Consequently, such knowledge persistently lacked acknowledged individual authorship or intellectual property rights. Innovations got integrated into the knowledge repository and, as circumstances altered, those aspects that became antiquated got modified or discarded.

A major shortcoming of oral transmission of knowledge is the lack of permanence in knowledge preservation. The oral tradition tends to deal with the current, deriving inevitably from the past. However, there are no records of the past to be accessed independently of those who carry the knowledge in their memory banks. In other words, the nature of the knowledge that prevailed in the past, or what aspects of that got altered with generational shifts, migration, as well as the influence of prevailing social/political currents on the interpretation of history, is not readily available. The formal schools that colonialism instituted brought two major changes to the conception or practice of education: Firstly, the content comprised knowledge systems, 
beliefs, cultural values, history, geography, political institutions, etc. of the colonialists; Secondly, the knowledge had been preserved and could be accessed in written form, with the guidance of a teacher. In brief, colonialist education involved "literacy", the ability to read and write. The invention of writing systems, facilitating the representation of language in a medium other than that of speech, profoundly affected aspects of culture and communication. This included modes of knowledge representation, preservation, transmission and, diffusion. Knowledge preservation no longer had to depend upon the memory capacities of individuals. Florian Coulmans, quoted in Connor-Linton (2006), noted of writing that it was probably "the single most consequential technology ever invented... Writing not only offers ways of reclaiming the past, but is a critical skill for shaping the future" (p. 403). The written medium even got credited with constituting the primary driving force behind western civilization. Emevwo Biakolo (2003) explicitly claims of western civilization that,

It owes its origin to writing. With the Greek invention of the alphabet, the organization of knowledge was radically transformed. In oral cultures, the poets, sages, and thinkers depend on poetic rhythm and narrative structure to ensure the remembrance of past utterances. With the introduction of writing, this mnemonic function is most effectively served by the medium itself, making the storage and retrieval of knowledge so much easier. (p. 14)

The content, comprising western knowledge systems, demanded the guidance of western or "appropriately" trained teachers. The requirement of literacy, not available in most African languages ${ }^{1}$, inevitably led to the transmission of the knowledge in European languages. While this appears to arise from pragmatism, it became the tool of colonial domination and control. Colonial education in Africa was not committed to transmitting the values and knowledge of African society from one generation to the next. Rather, it strove to change those values and to replace traditional knowledge with the values and knowledge systems of a different society (Babaci-Wilhite, 2016). Western knowledge systems and beliefs came to get identified with education, intelligence and civilization, bolstering "the premise of a superior race and the premise of a superior culture" that undergirded "European arrogance" (A. A. Mazrui \& A. M. Mazrui, 1998, p. 14), further serving to enhance and maintain power relations, and becoming the most powerful weapon for suppressing African values. Gary Urton, cited in Greer, Mukhopadhay and Roth (2012), claims that "European colonizers did not impose political and economic systems - and, most generally, worldviews - on blank slates, but rather strove to suppress and replace existing systems" (p. 12) ${ }^{2}$. Education is, thus, non-distinct from politics in relevant respects (Freire, 1970; Freire, 1998).

French colonialism, with its mission of assimilating the Africans to French civilization, was more spirited in the use of education for the dominance and spread of the French language. Of a French education, Senegalese Governor General Chaudié had this to say in 1897:

The school is the surest means of action by which a civilizing nation can transmit its ideas to people who are still primitive and by which it can raise them gradually to its own standards. In a word the school is the supreme element of progress. It is also the most effective tool of propaganda for the French language that the Government can use. (Crowder, 1962)

\footnotetext{
1 See Fallou Ngom (2010) for discussion of notable exceptions with the use of Ajami script in Senegal. John Mugane (2015) provides more relevant discussion of Ajami in his account of Swahili.

${ }^{2}$ Monica Kahumburu, commenting on an earlier version of the paper, remarked that this reminded her of her secondary school history class in Kenya. Discussing colonization she learned that in Gikuyu society a sect called "Akorino" emerged as a result of discontent with the impositions placed on the Gikuyu religion, culture, etc. especially with Christianity proscribing, inter alia, polygamy, female circumcision,

etc. (http://www.open.ac.uk/Arts/ferguson-centre/memorialisation/events/addis-workshop/tim-gachanga-paper-shtml)
} 
The French spared no efforts in the attainment of that goal. French colonial education contained an "explicit ideology of cultural assimilation (the policy was named 'association' in 1905), which reached its symbolic apotheosis with young African school children being taught songs about 'our ancestors the Gauls"” (Wiseman, 1990, p. 19).

British colonialism differed from that of the French largely in tactical arrangements in that it used indirect rule viz. using local leaders as agents of the administration ${ }^{3}$. However, in the education system that former British colonies inherited, the details were not radically different. While the British allowed the use of "... local languages in the early grades as part of their strategy of control", the French proscribed African languages in favor of French from the outset. In the upper grades, they both used their languages since "both French and British administrators sought to educate a small class of civil servants in the respective metropolitan languages" (Albaugh, 2014, p. 216). This was because with “... superior firepower, secure borders, and limited plans for industrialization, colonial rulers only needed a few administrative intermediaries and soldiers" (Albaugh, 2014, p. 216). Moreover, when the Germans ruled Tanganyika (now Tanzania), they promoted the use of Swahili for government and education largely because they pursued a policy that "... denied the colonial subject any access to the language of the colonial master" (A. A. Mazrui \& A. M. Mazrui, 1998, p. 55). Thus, while for the French "... no African was good enough unless he or she spoke French... ", for the Germans the belief was that "... no African was good enough to speak the German language” (A. M. Mazrui \& A. A. Mazrui, 1996, p. 273). French arrogance denied legitimation of native culture while Germans acknowledged it but maintained linguistic and cultural distance between the African "natives" and their rulers, between African culture and German culture. This contributed to the consolidation of Swahili in the territory. British policy vacillated between the two approaches, sometimes regarding the teaching of English to African "natives" as potentially subversive, except where or when it proved suitable for domination and control.

With emphasis on western knowledge systems, and under the guidance of European teachers or "appropriately" trained Africans, African education became elitist, training those who would eventually assume the reins of power in independent Africa (Bunyi, 2008b). It was Eurocentric in content and language. With regard to the content and ideology or educational policy it was, mutatis mutandis, similar to the education of African Americans, who got forced to "... adopt the European cultural heritage that dominates the educational milieu and thereby abandon their own cultural ties. Inevitably, as African Americans began to separate from their cultural tradition and assimilate into the dominant culture, they lost a degree of cultural identity and unity" (Hill, 1993, p. 682). In fact, a persistent view of public education in the United States is that it embodies the dominant systems that,

... have overwhelmingly supported the ideals and goals of white supremacy and are not arbitrary; they have been strategically crafted and executed. Schooling systems have functioned as channels through which members of the African Diaspora could be inundated with ideology that would stunt their political, economic, and social progress; thus, supporting the goals of white supremacy. (Givens, 2015, p. 1288)

This constituted the crux of what Wade Nobles (1986) labeled "conceptual incarceration" of the African, a term used to designate "the state of intellectual imprisonment in European value and belief systems occasioned by ignorance of African and Native American philosophical, cultural and historical truths" (Hotep, 2003, p. 6).

\footnotetext{
${ }^{3}$ Michael Crowder (1964) examines the colonial systems of the French and the British, noting that the direct rule of the French and the indirect of the British did actually share significant similarities.
} 
The elites coming out of African education were victims of conceptual incarceration, having got assimilated to European values and western knowledge, with corresponding alienation to their culture and knowledge systems. This explains the paradox of colonial domination and oppression-it was often not the poorest and most exploited but the more educated and relatively more privileged, those having closer contact with the agents of colonial domination, who felt most keenly the psychological and cultural impact of their subjugation (Fanon, 1967; Lee, 2015).

\section{Choice of Languages of Instruction}

The choice of language of instruction in African schools is not independent of the formulation of national language policies. African nation states, created by the colonial powers without Africans' participation or involvement, have the most artificial borders that have,

... fostered ethnic struggles, patronage politics, violence, and conflict, primarily by splitting groups across the newly-minted African states. Ethnic partitioning led to irredentism and helped create an ideology of secession and nationalism... African borders did not only split tribal homelands across countries, they also produced some of the largest and most heterogeneous countries in the world. (Michalopoulos \& Papaioannou, 2013, p. 1)

The creation and subsequent retention of highly arbitrarily drawn political boundaries placed different ethnicities within the same countries while simultaneously spreading some ethnic groups across different countries (Ungar, 1986). This resulted in multilingualism as a regular feature of African states, a situation decidedly different from that obtaining in the countries of the colonists.

When the Europeans came to Africa, they had already managed to settle on the nationhood of their presumably homogeneous states. They had enjoyed a period of relative stability and equality, a time of citizenship in a political sense. In the formation of those states "...a single language and a uniform way of speaking and writing that language were necessary conditions for the formation of a nation-state in a 'civilized' European fashion. Multiple dialects were discouraged in favor of single, uniform national languages" (Mugane, 2015 , p. 208). Biblical remarks in the Book of Genesis reinforced the conception of the nation as ".... people linked by birth, language and culture and belonging to a particular place” (Joseph, 2006, p. 22) ${ }^{4}$. However the concept of "a language" inevitably ".. demands denial of the primal diversity of variation... And here is where the politics clearly enter-for whatever is identified as the good or correct form of the language empowers those who have it as part of their linguistic repertoire, and disempowers those who don't" (Joseph, 2006, p. 44). Noam Chomsky (1986) adds to the political aspects of "language" with the observation that the notion involves "crucial socio-political dimensions" (p. 15).

African leaders largely embraced such a conception of nationhood, believing that political cohesion required a standard national language. To achieve political unity, nationalist leaders initially opted for one-party states. However, the prevalence of multilingualism posed apparent problems in the selection of a national language or language of wider communication. While historically, rulers and their bureaucrats preferred a single, standard language in order to approach citizens directly, without the mediation of regional elites, the new leaders had vested interests in retention of power. Their elitist western education, obtained in European languages, proved instrumental to that end. Since the European languages had already served as official languages, pragmatism demanded their retention in that capacity, entrenching their position of power within the independent states. Further, the lack of published material in African languages provided additional argument

\footnotetext{
4 The Biblical reference alluded to here is The Book of Genesis Chapter 10 verse 5
} 
for the use of European languages in education. This reinforced the prejudice that African languages, lacking any written tradition, could not be regarded, even by their own speakers, as "languages" (Joseph, 2006).

Besides, the European languages had also been instrumental in the progress of science and technology, and were deemed crucial to economic development. The situation has virtually remained unchanged in the majority of African countries even as they celebrate golden anniversary of independence. Bokamba (2011) has noted that

From a decolonization or liberation perspective, one of the surprising outcomes of the continent is that the language policies in 34 out of the 54 African states, excluding the newest state, South Sudan, remain to-date characteristically static in the sense that they have maintained the legacies of the former colonial powers. Typically in these cases the languages of the colonial masters, viz., English, French, and Portuguese, are utilized as the exclusive media of governance, education, mass media, and international communication. (p. 147)

This has resulted in the relegation of African languages to an inferior status, viewed as not fit or adequate for representation or delivery of knowledge. For instance, in Zimbabwe, English gets esteemed above the local languages. To speak English is identified with intelligence, whereas to speak Ndebele, Shona, Tonga, etc. gets equated with ignorance. In Zimbabwean primary schools, especially in the urban areas, children detest the Shona language ${ }^{5}$. Education in Africa has yet to discard the image of elitist training where foreign knowledge systems are taught in foreign languages, detached from the local epistemological, linguistic or "cultural context". It is de-contextualized education (Mchombo, 2014, 2016).

The role of language of instruction in education is of serious gravity in that the choice of language of instruction directly impacts the degree of comprehension of the material learned. The sad commentary is that in African education "there are pronounced incongruities between the language the child understands, the language of the parent, and the language of schooling. Often the language of the child is also different from that of the teacher and both do not have command of the language of instruction" (Mugane, 2006, p. 14). The reality is that the choice of language of instruction is far from irrelevant to the degree of mastery of the material learned. The proscription of the child's first language in favor of an unfamiliar language reduces learning to rote memorization, with minimal comprehension. Mugane has referred to the non-use of the child's first language as "linguistic incarceration", an echo to "conceptual incarceration" of Wade Nobles. Mugane (2006) observes that,

The first language of the child is incarcerated, reducing education to the pursuit of fluency in English mediated by markedly non-proficient instructors. Whenever the switch is made from the child's first language to the language of the school there is always an instructional blackout. For the vast majority of children, the blackout is total and final. Learning is then reduced to verbatim memorization (and in numerous cases good hand writing)! To arrest the use of indigenous languages where they are most needed begins the process of necrolinguistics, the erasure or non-mastery of the vernacular. (p. 14)

This view is echoed in various studies (Bunyi, 1999, 2008a; Gacheche, 2010; Kamunyu, 2013; Muthwii, 2002, 2004, 2007).

\section{Cultural Links and International Aid}

Independence in Africa did not sever economic or cultural links with the colonialist regimes. Confronting

\footnotetext{
5 I am grateful to Sibusisiwe Mukwakwami (personal communication) for this observation about the use of language in education in Zimbabwe.
} 
intolerable levels of poverty, illiteracy, disease, and the scarcity of human and material resources, African countries have been compelled to seek international aid from international organizations such as the International Monetary Fund (IMF), the World Bank, or the former colonial regimes and more industrialized nations, the core countries, placing them on the periphery. The dependency has impacted the policies in language in education. Considering that the IMF and the World Bank are the principal organizations through which the capitalist West seeks to control the destiny of the rest of the world, “... the establishment and reconstruction of structural inequalities (in institutional set-ups and financial allocations) and cultural inequalities (including attitudes, pedagogic principles, etc.) between the imperial European languages and other languages become indispensable strategies towards that attempted control" (Mazrui, 1997, p. 43). The dependency relation of the periphery on the core centers has ensured continued western domination of African politics, economic performance, and educational practice. Imperialism is, thus, not dead. Robert Phillipson (1992), who views the use of English as "linguistic imperialism", characterizes imperialism as a relationship by which one society can dominate another, through four mechanisms: exploitation, penetration, fragmentation and marginalization. According to Phillipson (1992), "there are centers of power in the center and in the periphery. The peripheries in both the center and the periphery are exploited by their respective Centers (p. 52).

The cultural imperialism that facilitates the mechanisms indicated above includes the constant requirement that European languages remain the media of instruction in African education (Babaci-Wilhite, 2015). Arguments supporting offering education in the children's languages, acknowledged as a fundamental human right (UNESCO, 1953), get short shrift. The need to appease the "expatriate advisors from the donor countries and agencies" strengthens the view that "the colonial mind in African education has been perpetuated under the guise of international development", so that, through the intervention of international aid from donor countries, African education has reduced to "an export commodity from the center and is accepted in Africa as a result of Western-based ideas of what it means to be developed" (Babaci-Wilhite, 2015, p. 18). The economic dependency of the "periphery" countries on the countries of the "center" has translated into the English media from the developed countries (the center), penetrating the media of the developing nations (the periphery). This penetration, comprising the content of globalization, has eroded the national sovereignty, cultural identity, and political independence of developing nations (Pennycook, 1994; Zeleza, 1997). Dependency theorists argue that the global economic system keeps weaker "peripheral" states, largely former colonies, in permanent economic dependence on the more powerful states of the "center", including the former colonial powers.

Then there is the prevalence of negative attitudes towards African languages. These are not merely widespread but "surprisingly, shared by many African people and expatriate government advisors" (Wolff, 2006, p. 32). According to Obanya (1999), the negative attitudes towards African languages are deeply rooted in the fear of social change among members of the post-colonial elites as well as on the part of their expatriate advisors from donor countries and agencies. The latter balked at the potential for marginalized sections of the population, illiterates, women, and even children to become empowered through official recognition of their languages, a fact that would detrimentally affect the balance of power and threaten the privileges of the dominant elite. It is against this background that the politics of choice of language in African education can be understood. We will proceed to comment on the countries that comprise the case studies.

\section{Kenya Postcolonial Language in Education Policy}

In February 2014, the Ministry of Education in Kenya decided to "enforce" the language policy that had 
been in place for three decades. The policy required that children in lower primary schools should be taught in a mother tongue ${ }^{6}$. Despite the policy being in place for a very long time, people did not seem to be aware of it.

During the colonial period the missionaries, with the cooperation of the colonial government, were the chief providers of western-type education. While some of the missionaries developed orthographies in some of the indigenous languages and emphasized the teaching and use of these languages, education remained heavily dependent on the use of English. The use of local languages suited the missionaries' agenda of proselytization. They believed that spiritual communication with Africans could best be achieved within the tribal context. The evangelicals "... regarded the preservation of African languages as an essential component of their attempt to capture the African soul" (A. A. Mazrui \& A. M. Mazrui, 1998, p. 55). Following the attainment of independence from Britain, Kenya set up the Ominde Commission to review, inter alia, language in education. With regard to language in education, the Ominde Commission came up with the following policy recommendations:

(a) English should be the medium of instruction from Standard 1;

(b) Indigenous languages were characterized as "essential languages of verbal communication";

(c) There was no reason to assign them a role for which they are ill adapted, viz., the role of educational medium in critical years of schooling (Republic of Kenya, 1964, p. 60).

The Ominde Commission's report clearly reflects the colonial origin of formal education, forcing the retention of English as the medium of instruction and of, effectively, Eurocentric curricula. The indigenous languages, while good for verbal communication, were deemed ill adapted to representation and delivery of knowledge. According to the Ominde Commission report, they recognized "... no difficulty in including a daily period for story telling [in the indigenous languages] in the curriculum of primary one, two and three" ${ }^{\text {" }}$. In other words, the local languages were to remain confined to oral presentations of traditional stories but excluded from the culture of literacy. Admittedly, the linguistic-cum-ethnic diversity of Kenya constituted a relevant factor. That, taken in tandem with the lack of trained teachers or educational material in any of the local languages, as well as the fabled unsuitability of the local languages for education, easily "forced" the retention of English for an education that would prepare the youth to contribute to national development. According to Mzee Jomo Kenyatta, the first President of the Republic of Kenya, national development would crucially involve tackling ignorance, disease, and poverty (Bunyi, 2008a) ${ }^{8}$.

The policy got revised with the Gachathi Commission report of 1976 (Republic of Kenya, 1976). The Gachathi report recommended the use of local languages for the first three years of instruction. In other words, indigenous languages should have a "bridging" role for the first theee years, as children made transition from the languages of home. It is this policy that the Ministry of Education of Kenya wanted to enforce (Gacheche, 2010). The policy had not really received much attention because, for rural parents, education comprised the place where children went to learn English not indigenous languages which they already knew and where, for urban parents, English was the medium of instruction (Muthwii, 2002). Further, colonial education was based on racial segregation with separate schools for the whites, Asians, and the Africans. Since the examinations for

\footnotetext{
${ }^{6}$ Retrieved from http://www.nation.co.ke/oped/blogs/dot9/great-need-for-children-to-be-taught-in-mother-tongue/1959700-217 0334-9vu24v/index.html

7 Ominde Report of 1964 on Education in Kenya. Retrieved from https://softkenya.com/education/ominde-commission/

${ }^{8}$ Grace Bunyi (2008a) provides an excellent account of the evolution of Kenya's education policies. It would be beneficial to read it.
} 
matriculation were set in English, the association of English with power, elitism, success and, especially, intelligence, became inevitable?

This latter is nontrivial. Ngugi wa Thiong'o (1986) noted that during colonial times African children learnt to associate their mother tongues with stupidity, humiliation and low status, and the language of the colonizers, English, with intelligence and success, as noted above with regard to the attitudes towards Shona in education in Zimbabwe. Further, because in Apartheid South Africa, Bantu Education that promoted the use of African languages had the political motivation of entrenching unequal power and continued denial of economic opportunities to, and general oppression of, the African people, there was negative reception of use of African languages in education. The political ideology reinforced the perception of inferiority associated with the use of African languages in education. This legacy of undermining local languages and placing foreign ones on a pedestal still prevails in several developing countries (Bamgbose, 2011; Kamwendo, 2015; Kishindo, 2015; Moto, 2009; Mtenje, 2013; Ngonyani, 1997; Simango, 2015). Thus, the conception of education as comprising the transmission of foreign (western) knowledge systems, learning English, and using English as the language of instruction, remains standard in many African countries, certainly those that had been under British colonial rule. The British Council, whose overall aim lies in the field of cultural relations, has contributed to the maintenance of English in educational institutions and in the cultural fabric of the former colonies. After all, its “...more specific objective has always been to develop a wider knowledge of English in the world. This objective is most often fulfilled through facilitating the teaching and learning of English in public education systems" (Knagg, 2013, p. 70). In fact, the British Council remit as expressed by the British Crown is for the expansion and consolidation of British culture and the English language across the globe. The Royal Charter of 1940 that formally promulgated its establishment points to "promoting a wider knowledge of the [United Kingdom] and the English language abroad and developing cultural relations between [the UK] and other countries" $"$. This is amply demonstrated in the British Council Annual Report 2009-2010: English Next India. The Report states that: "From education to the economy, from employability to social mobility, the prospects for India and its people will be greatly enhanced by bringing English into every classroom, every office and every home" (Phillipson, 2014, p. 8). Other cultural agencies of the former colonial regimes must have comparable objectives.

\section{On Implementation of Mother Tongue-Based Education}

Facing chronic disappointing students' performance in Kenyan education, the question of revisiting the language policy became legitimate. Thus it was that in 2014 the then Cabinet Secretary for Education in Kenya, Prof. Jacob Kaimenyi, expressed his support for the implementation of mother-tongue education in lower primary grades. He appealed to the standard view that "the use of local languages in the formative stages of child development was critical and had scientifically been proven to be productive"11. One advocate of the policy, John Othieno (2014), pointed out the difficulties of teaching four-year-old children in a language whose structure, format and grammar they do not understand ${ }^{12}$. The issue is that it is distressful for children to learn the language and at the same time grasp scientific, mathematical and linguistic concepts in the "unlearned"

\footnotetext{
9 Grace Bunyi (2008a) remarks on the racial segregation that prevailed in Kenya's education in footnote 1.

${ }^{10}$ Retrieved from https://www.britishcouncil.org/organisation/history

11 Retrieved from http://www.nation.co.ke/news/Use-local-languages-insists-minister/1056-2229690-jek7ez/index.html

12 Retrieved from http://www.nation.co.ke/oped/Opinion/Our-vernacular-languages-are-the-best-method-to-teach/ 440808-2199116-7c0kfyz/index.html
} 
language. The commonly held view is that a child's initial acquisition of language is vital to learning how to think. Therefore, when an education system imposes a foreign language on children, disregarding their initial contact with language and pattern of processing new information, it inhibits their development of cognitive function (Chumbow, 2013; Hale, 1974; Pearson, 2016; Wigglesworth \& Simpson, 2008, p. 14).

Common as this view is, the enunciation of the implementation of this policy in Kenya was greeted with opposition. The most vocal critics turned out to be the teachers. Predictably, the arguments ranged over the anticipated or usual terrain viz., that there were neither materials in the languages nor qualified teachers for that; that the policy merely exacerbated the ethnic divisions through its support of ethnic identity and loyalty, thereby undermining the political goal of achieving national unity and identity; that the policy is retrogressive and fails to factor in the knowledge required for economic and technological advancement in the world of the 21 st century etc. (Gacheche, 2010; Khejeri, 2014; Kioko \& Muthwii, 2001, for more general observations). Consequently, the Kenyan government's effort to introduce teaching in mother tongue came to a screeching halt when "the motion was strongly protested against" ostensibly ".. because it would promote tribalism". This brought into sharp relief of the great linkage "... between language and politics especially in Africa, as the colonialists contributed to the development (both positive and negative) of language" ${ }^{\text {13 }}$. The reliance on foreign languages as languages of instruction in education negatively impacts literacy in both the local languages and the foreign languages. Not only do the people fail to gain literacy in their languages but they also discover that gaining proficiency in English is, for many, including the teachers, a major challenge. Simango (2015) states it succinctly that “... relying on an unfamiliar language to disseminate knowledge has a number of disadvantages to start with. Not only do many learners fail to become literate in the target language, but also very few people, if any, learn and become functionally literate in their mother tongue" (p. 54).

The situation in Kenya is of particular significance because the multilingualism that is traditionally blamed for the possible entrenchment of ethnic tensions with negative effects on national unity should get offset by the presence of a local language, Kiswahili, that is co-official with English. While the problems associated with the implementation of mother tongue education could, conceivably, work in favor of Kiswahili gaining more prominence in education, the situation remains unsettled. For a start, while Kiswahili gained prominence during the colonial era when the British initially chose to promote and standardize it as a way to "make their subject societies more legible or, in other words, more efficiently governable", its fortunes got reversed in the 1940s "after realizing Kiswahili's potential as a tool for anti-colonial organizing" (Marshall, 2015, p. Ii). The colonialists recognized, and used, language as a tool of political control (Fanon, 1967; Pennycook, 1994). Kiswahili's instrumentality to the advancement of political ideology of Ujamaa in Tanzania, contributing to its elevation to official language status there (Blommaert, 2006), and its spread from the Indian Ocean littoral into the "heart of Africa" and beyond, as well as its adaptability to multifarious demands (Mugane, 2015), contributed to its emergence as the most recognizable lingua franca in, especially, East Africa. In Kenya, it is the language that the majority of people of various ethnicities have some command of. As such, it would be expected to fare much better in education. In fact, Kenya's language in education policy advocated the use of mother tongues in the initial stages of schooling, shifting to Kiswahili then English in the higher levels. This would respect rights in education (Babaci-Wilhite, 2015, Babaci-Wilhite, Geo-JaJa \& Lou, 2012; Brock-Utne, 2007, 2012a, 2012b; Prah, 2013). Further, use of mother tongue maintains the children's cultural grounding. In

\footnotetext{
${ }^{13}$ I am grateful to Louisa Chinyavu Mwenda for this observation, made in email communication.
} 
brief, vernacular languages, just like music and arts, cuisine, religion, social habits, etc., are part of the culture of the people, hence should not be ignored in the children's education.

The basis for disfavoring Kiswahili is that, for a start, both Kiswahili and English are "additional/second languages for many people because, for many Kenyans, the first language is the language spoken in their tribes" (Sibomana, 2015, p. 37). With an estimated 42 different ethnic groups in the country, there is alleged lack of uniformity in usage or competency among the various regions of the country. Even the children in urban areas lack the requisite proficiency in "standard" Swahili, having fallen under the influence of the youth variety that is called Sheng (Githinji, 2008; Githiora, 2002). Strictly speaking, this factor should count just as much against the use of English. Many people face comparable, if not worse challenges, with that language. The arguments against Kiswahili derive, therefore, not from factors relating to proficiency that are peculiar to it. Rather, they are rooted in the perennial argument that Kiswahili, or African languages in general, are not suited to science, technology, engineering, or math (alias STEM) education, critical to development etc. The discourse continues to emphasize the need for the strengthening of the teaching of English, invoking its centrality to science, technology, and globalization. The argument is that English is the language of science and technology and that school curricula should emphasize computer-based technology and English as the language of such technologies (Bunyi, 2008a; Neke, 2003). In addition, Kiswahili, like other local languages, is not the language of examinations. Hence, the language policy inherently favors an English-speaking elite by setting final examinations in English. Thus, English continues to be the chief screening determinant as to who accesses higher education and therefore jobs and other social mobility mechanisms.

\section{Malawi the Colonial Language Policy}

While not as expansive in size, as rich in resources, or as strategically located as Kenya, Malawi shares with Kenya the history of British colonialism. Lying south of Tanzania in the Great Rift Valley, wedged between Mozambique to the east, south, southwest, and Zambia to the west, Malawi is a small country of landmass of 118,484 square kilometers. Of that, 24,000 square kilometers is taken by Lake Malawi ${ }^{14}$ that dominates the country's landscape. Currently Malawi's population is estimated at 17 million, providing home to a diversity of ethnicities and the various languages within its borders. Of these the major ones are Nyanja, Lomwe, Tumbuka, Yao, Tonga, and Sena, as well as some minor ones, such as the Lambya, Nkhonde, Nyakyusa, Nyiha, and Nsukwa/Ndali. Traditionally, the Nyanja people have comprised the majority (Kishindo, 1990; Matiki, 1997; Mchombo, 1998b; Young, 1949).

During the colonial era the British recognized the importance of chi-Nyanja - the language of the Nyanja people - which could facilitate their control of the local population to ensure effective government. As a consequence, the colonial government adopted the use of chi-Nyanja as the official language in some parts of the country. To facilitate the learning of the language, the government adopted it as an official language. The government justified that move with the observation that " $[\mathrm{I}] \mathrm{n}$ Nyasaland... the Nyanja speakers not only outnumber those of other areas, but their dialects have a much longer history of literary use" (Price, 1940, p. 129). The adoption of chi-Nyanja as the official language gave the impetus for it to be taught in schools.

\footnotetext{
14 The countries of Malawi and Tanzania have, yet, to resolve disputes about whether the whole of the lake belongs to Malawi or part of its northern waters is in Tanzania. Speculation that the lake may have oil reserves has only led to escalation of the border disputes. The result of the on-going dispute has been that the Tanzanians use the old designation of Lake Nyasa to refer to the lake, while the Malawians refer to it as Lake Malawi. I use the designation that the Malawians use without trying to prejudice the issue.
} 
Further, knowledge of the language was required for work within the government. Hailey (1938) summarized the language situation in Malawi (then Nyasaland) as follows: "Nyanja has been adopted as the official language by the government. Knowledge of it is compulsory for departmental examinations and it is intended to introduce it into all schools after two years instruction in the vernacular" (p. 75). In other words, the language in education policy that prevailed during the colonial period seems comparable to that of Kenya. The local languages were to serve as Languages of Instruction (LoI) during the first two years of schooling subsequently yielding to English while chi-Nyanja was studied as an official language (Mchombo, 2000, 2009).

\section{The National Language Policy of Independent Malawi}

Chi-Nyanja, the language that the British colonial administration selected to make the official language of Malawi, had a number of dialectal variations. Of those the one that came to feature prominently in the post-independence era was the variety called chi-Chewa. Associated with the Nyanja who lived in the hinterland, away from the shores of Lake Malawi or the banks of Shire River that flows from the southern extremity of Lake Malawi to the Zambezi River, extending into the Eastern Province of Zambia, it was the dialect that was the linguistic heritage of the first president of independent Malawi, Dr. Hastings Kamuzu Banda. Publications on the language during the pre-independence era always referred to it as Nyanja. There was one singular exception. Mark Hanna Watkins, an anthropologist at Fisk University in Illinois, had his doctoral dissertation published in 1937 as supplement to the journal Language, the journal of the Linguistic Society of America. The publication bears the title of A Grammar of Chichewa: A Bantu Language Spoken in British Central Africa. The author states in the introduction that,

[T]he Achewa are found principally in the Kasungu, Dowa, and Lilongwe Districts of Nyasaland Protectorate, British Central Africa. Their territory extends eastward as far as Lake Nyasa and westward into North-Eastern Rhodesia. Ethnically, they are a division of the Nyanja group, which has its center in the Shire Valley and Highlands of the Southern Province and in the Central Province southwest of Lake Nyasa, extending as far north as the middle of the lake.

Watkins (1937) proceeds to state that "The Nyanja language, of which Chichewa (= the Chewa language) is only a variant, was classified by Father J. Torrend as a member of the 'Senna Cluster' of his 'Main Group' of Bantu languages" (p. 5). The dialect status of Chichewa is clearly stated. What was also significant about the dissertation of Mark Hanna Watkins was his source of information. Acknowledging his language consultant Watkins (1937) states: "All the information was obtained from Kamuzu Banda, a native Chewa, while he was in attendance at the University of Chicago, from 1930 to 1932" (p. 7). This is the Kamuzu Banda who became the first president of independent Malawi.

The ascendancy of chi-Nyanja was the direct result of actions of the missionaries and the British colonialists. In other words it was the politics of colonial domination and control that, very much like Kiswahili in Kenya and Tanzania, favored chi-Nyanja to become the official language of Malawi. With independence, and a nationalistic Chewa as the president, the fortunes of chi-Nyanja underwent rapid erosion. Watkins indicated that Chichewa was a dialect of Nyanja. Unfortunately, the term "dialect" holds rather negative connotations for many people. A language is assumed to be a "developed" system, with grammatical rules, a rich lexicon, used in education and in various transactions in the modern civilized, industrialized and technological world. It also has a literary heritage. Dialects, on the other hand, have the connotations of undeveloped primitive systems, without grammatical rules, etc. Nurse and Hinnebusch (1993) make the following observation about this distinction: "One would define language as national and dialect as local. A 
second defines language as the standard, written form; dialect as the nonstandard, substandard, or unwritten form" (p. 37). Chichewa, as a dialect, would fit the profile of a primitive, backward system of communication, used by uncivilized people. Kamuzu Banda proceeded to reverse that classification, arguing that it was chi-Nyanja that was a dialect of Chichewa. In 1968, four years of an independent Malawi with Hastings Kamuzu Banda in firm control of the government, a national language policy was forced on the nation at the annual convention of the then ruling and sole legal political party, the Malawi Congress Party. The resolution made Chichewa the "national" language while "relegating" chi-Nyanja to dialect status (Matiki, 1997; Mchombo, 1998b; Moto, 2009).

\section{Approaches to Language in Education Policy in Malawi}

The elevation of Chichewa to "national language" was more of a decree from the dictatorial rule of Kamuzu Banda than it was a "policy" as such. There had not been any deliberations that involved either the lawmakers or the general public. The annual Malawi Congress Party Convention merely effectively gave public pronouncement of what had been decreed. Kishindo (1996) makes it plain with the comment that "In 1968, however, before any consultations had been conducted, Dr. Banda announced to the annual Malawi Congress Party Annual Convention his interest in having Chichewa a national language. Following his speech to this effect the convention delegates did pass a resolution to that effect" (p. 58).

The logic of a "national language" included the routine pronouncements of unity, national identity, nation building, etc., all assumed achievable through "one nation, one language" policy. In Malawi this extended to political parties, opting for one party system making opposition parties illegal (Mchombo, 1998a). The elevation of Chichewa marginalized other local languages, especially Chitumbuka, the language of the Tumbuka people who predominate in the northern region of Malawi, spreading into Zambia as well. Together with Chichewa, Chitumbuka had shared presence in the print media and radio programming. With the decree making Chichewa the national language that immediately ceased, all mass communication would be in the two languages, English (the official language), and Chichewa (the national language) ${ }^{15}$.

The new politically inspired status of Chichewa did have an impact on the language in education policy. The Ministry of Education, as a crucial institution in the implementation of the language policy, declared, in 1969/1970, that English would become a "mandatory subject for educational and general purposes up to school certificate level. At primary level Chichewa was to serve as a LoI for the first five years, thereafter English was to take over while Chichewa remained a subject. At secondary school level Chichewa was to continue as a subject" (Kishindo, 1996, p. 61). A Chichewa Research Committee, later called the Chichewa Working Group, was set up and tasked with preparation of a National Dictionary of the Chichewa Language. This came to operate under a specially formed Chichewa Board whose functions were to: (a) provide the national dictionary of the Chichewa language; (b) produce Chichewa orthography rules; and (c) develop the Chichewa language.

The University of Malawi had opened its doors for undergraduate training in 1965 and, with the new policy, Kamuzu Banda directed that there should be presence of Chichewa studies there. The present author, ironically an ethnic Nyanja, was the university's response to that directive ${ }^{16}$.

15 Retrieved from http://mwnation.com/chitumbuka-has-been-demonised/

16 Kamuzu Banda expected the University administrators to identify a Chewa candidate. When the present author's name was forwarded to him as the potential scholar to pioneer studies of Chichewa and Linguistics in the university, with the statement that the selected candidate was of Nyanja ethnicity, he objected to the choice. However, he had a change of heart but insisted on interviewing the present author personally. 
The politics behind the elevation of Chichewa contributed to the subsequent dominance of Chichewa in the cultural fabric of Malawi. It became the most widely spoken language, even in areas traditionally viewed as strongholds of other languages. ${ }^{17}$ However, this did not extend to education. In fact, Kamuzu Banda pretty much undermined the use of Chichewa as the main language in education. A dyed-in-the-wool Anglophile, Kamuzu Banda, despite his passion for promoting Chewa culture and language, no longer spoke his own language, requiring an interpreter to translate his speeches. Not only was Banda deeply influenced by British values and educational system, especially in the post-WW II period, his attitude towards the study of grammar was that it required understanding of Latin and classics. The teaching of Latin in Malawian secondary schools got discontinued in the 1960s. It had been declared a "dead" language on account of its lack of active usage. French replaced Latin as the "foreign" European language. Kamuzu Banda, who had a deep desire to see improvements in academic standards, decided to open his own school, the Kamuzu Academy, in his home district of Kasungu. ${ }^{18}$ The intention was to expose gifted students to a vigorous and stimulating program with a curriculum that had, as its core component, classics. According to Banda, without grounding in classics, "no man can truly call himself educated"19 (Kishindo, 1996, p. 13).

The establishment of the Kamuzu Academy, lavishly provided for, with its emphasis on classics, compelled the Ministry of Education, as well as the University of Malawi, to respond appropriately. There was a scramble for the (re)-introduction of studies of Greek, Latin, and classics in general. The attention that the teaching of classics garnered effectively eliminated the momentum for Chichewa. In fact, Banda had undermined it even as a subject through not having it offered at the Academy. Kishindo (1996) puts the matter succinctly thus: "Banda the Africanist had given way to Banda the Classist" (p. 66).

The departure of Kamuzu Banda from the political scene, combined with Malawi's economic hardships, may have abated, or forced reviews of, the study of classics. However, that did not affect the increased significance of English. The perennial under-performance of school children continually got blamed on poor standards of English. In an effort to reverse the trend, the Ministry of Education decided that proficiency in English would improve remarkably if students were to receive instruction in English from the onset of their education. Thus, in March 2014 the Ministry of Education in Malawi announced that all subjects would have to be taught in English, with the exception of, predictably, the local (national) language, Chichewa. Making the announcement, the then Minister of Education, Dr. Lucius Kanyumba, claimed that this would be in line with "a new Education Act which will see pupils being taught in English right away from Standard 1"20. Implicit in this policy is the view that proficiency in English will also facilitate acquisition of knowledge in math and science. Of course the Education Act in Malawi did not usher in anything particularly novel. It had been more

\footnotetext{
17 During a visit to Mzuzu in 1997, the regional capital of the predominantly Tumbuka area, the present author noticed that Chichewa was quite extensively used. The nearly 30 years of Chichewa pushed as the national language had, certainly, had some effect.

18 Kamuzu Banda's emulation of the British grammar school model, complete with dress code requirements for the students, the focus on Classics, and the non-use of African languages on campus, led to the common (somewhat unflattering) reference to the Kamuzu Academy as the Eton of Africa. It did not help that Kamuzu Banda stated it quite bluntly that there would be no black people teaching at the Kamuzu Academy. The implications of that on his views of how African teachers and African languages would impact the quest for high academic standards were not lost on Malawians. The Kamuzu Academy was an elitist institution par excellence, without connection to anything local, except its physical location.

${ }_{19}$ Kamuzu Academy Program of the fifth Anniversary of the Founder's Day, Friday 21 November 1986 and a Brief History of the Academy.

${ }^{20}$ Retrieved from http://www.nyasatimes.com/2014/03/05/malawi-std-1-pupils-to-start-learning-in-english-all-subjects/
} 
or less adhered to even as statements about use of local languages in lower primary education maintained a nebulous presence in policy documents (Kishindo, 1996). Education in that country has traditionally been delivered using English as medium of instruction, with plenty of emphasis on the use of English in official settings. The use of Chichewa as medium of instruction, let alone in government or official duties, was either proscribed, certainly in parliament (Matiki, 2002; Mtenje, 2013) or muted. In brief, the conviction lingers on that while African languages may be useful for use in oral tradition, for poetry and fiction or drama, they are not suited for scientific discourse with all the mathematical concepts and calculations or logical inferences that characterize its formulation and mode of delivery (Kwok, 2015; Rugemalira et al., 1990; Williams, 2011). The fact that the resort to English continues to remain an impediment to learning in elementary stages of schooling, as noted in a recent article ${ }^{21}$, has not (yet) engendered a review of the language in education policy. In fact it is safe to say that such a review is not imminent, considering the prevailing social attitudes towards African languages.

\section{On the Alleged "New Colonization" By China}

The paper opened with a statement about the opposition that Sadtu expressed to the South African government's demand to introduce the teaching of Chinese in the schools. Sadtu rejected it as constituting a "new form of colonization". The charge is, in relevant respects, if not unwarranted then premature. China's emergence as the second most powerful economy has fueled its quest for raw materials. To gain access to resources in African countries, China has aided in financing and building much needed infrastructure (Espositi $\&$ Tse, 2015). African countries, as beneficiaries of the generous investment, feel ethically and politically obliged to "learn" Chinese culture, and accommodate Chinese policies. The neocolonialist charges derive from the perception that,

The "...unequal relationship between subjugator and subjugated is being recreated" and many European and American commentators "have been accusing China of enacting... a strategy to assume sovereignty of countries across the world, including some of the most politically underdeveloped and economically (albeit resource-rich) poor economies, particularly many in Africa”. (Moyo, 2012, p. 157)

Such political evaluation of Chinese foreign policy runs counter to the basic definition of colonialism. So far, China appears to have remained "... disinterested in assuming sovereign responsibility and particularly in shaping the social and political infrastructure of host nations..." (Moyo, 2012, p. 157). However, China has used its economic leverage to promote Chinese culture and, significantly, its language (Mandarin) in those countries. In Kenya, in the year 2014 Kenya Institute of Curriculum Development KICD held meetings with Kenyatta University Confucius Institute on including Chinese Language in the revised curriculum that is to be implemented in 2017. The teaching of the language is to begin from sixth grade. Confucius Institutes, strategically located in educational institutions, have provided the locus of the spread of Chinese language (Mandarin) and culture, and have started creating awareness of the language by setting up clubs in primary and high schools. In this, the establishment of Chinese Language and culture clubs in secondary (high) schools is proving instrumental, as has been the case in Kenya ${ }^{22}$.

\footnotetext{
${ }^{21}$ Retrieved from http://mwnation.com/whats-in-a-mother-tongue/

22 I am grateful to David Kyeu for bringing this to my attention. Retrieved from https://www.africanewshub.com/news/376780-catching-them-young-with-chinese-language-clubs
} 
Further, China has initiated "Chinese Bridge"-Chinese Proficiency Competitions for secondary school students. The Chinese Bridge is a Chinese language proficiency competition initiated by the Chinese Hanban (Confucius Center), with the purpose of encouraging more youth around the world to learn and understand the Chinese Language and culture ${ }^{23}$. On the occasion of the eighth "Chinese Bridge" Chinese Proficiency Competition in Malawi in 2015, China's ambassador to Malawi, his excellency ambassador Zhang Qingyang, claimed that with the rapid development of China, “... the Chinese language has been considered more and more important internationally, and its importance has been realized by most countries in the world. Learning Chinese has become a new trend and new fashion"24. In Kenya the Confucius Institutes are in almost all public universities (Nairobi University, Egerton University, Moi University, Kenyatta University, etc.). In Malawi, the Departments of African Languages and Linguistics, and of Philosophy, at the Chancellor College campus of the University of Malawi host the Confucius Center. While Malawi has not yet come out as openly as South Africa in requiring of the students that they learn Mandarin, China continues to make inroads with Mandarin and Chinese culture. The annual "Chinese Bridge" Chinese Proficiency Competitions targeting secondary (high) school students constitute one avenue. The other outlet has been through the media ${ }^{25}$, most especially the state sponsored broadcasting unit, the Malawi Broadcasting Corporation (MBCTV) that regularly airs Chinese cultural programs ${ }^{26}$. This is in a country where, like in many other African states, politicians and “...most stakeholders (particularly parents) are not in favor of their children learning in the vernacular languages even though research shows that countries that are developed use their indigenous languages" (Edrinnie Kayambazinthu, personal communication). The Chinese may not yet fit the classical definition of colonizers but for many Africans the belief is that just as the Westerners used Christianity to take root in Africa, the Chinese are using Confucianism to take root in Africa. They have used their economic might to set up Confucius Institutes and classrooms, laying emphasis on teaching and spreading of Chinese Language and culture. However, they, in return, have no interest in the African languages, culture or local society's systems ${ }^{27}$.

The irony here is that the charge of Chinese colonialism in South Africa arose because, as South Africa's biggest trading partner, the South African government resolved that it was important for the children of South Africa to "become proficient in the Confucius language and develop a good understanding of Chinese culture" (Nkosi, 2015). This attitude has rarely been extended to the ex-colonial languages, that they should be studied because of their importance to the relations with their speakers. Instead, those retain the right to remain dominant in all arenas of power and education without reduction to their colonialist tinge.

China's investment in its culture and linguistic heritage should really be contrasted with the lack of comparable commitment by African regimes towards their own cultures and languages. Arguments based on the unsuitability of African languages for science and math education, or for technology, remain something of a

\footnotetext{
${ }^{23}$ Thanks to Pui Ki Patricia Kwok for drawing my attention to the annual "Chinese Bridge" Chinese Proficiency Competitions in Malawi and other countries.

${ }^{24}$ Retrieved from http://mw.china-embassy.org/eng/dsxx/dsjh/t1267679.htm

25 The use of the local media complements the establishment of Chinese broadcasting in Africa. Central China Television (CCTV) for Africa has been operating from Nairobi, Kenya, for a few years now. Besides news, viewpoints, current affairs, etc., there is much concerning Chinese culture.

${ }^{26}$ I am grateful to Edrinnie Kayambazinthu of the University of Malawi for this insight and for her comments on politicians' and parents' attitudes towards the use of local languages in education.

27 This view, echoing the reaction of Sadtu, dominated the discussion session after the presentation of a paper on the teaching of Mandarin in Kenya at the 20th Annual Conference of the African Language Teachers Association (ALTA) held in Atlanta, Georgia, 22nd-24th April 2016.
} 
"red herring" (Mchombo, 2016) ${ }^{28}$. They are simply politically inspired without any empirical evidence adduced to sustain the belief. Case in point, the uproar in 2015 to eliminate Afrikaans as language of instruction at Stellenbosch University in South Africa did not invoke alleged grammatical or lexical deficiencies of the language to express science or technology concepts ${ }^{29}$. The whole argument was purely political, forged as “...part of a movement to 'decolonize' higher education". Afrikaans posed difficulties for non-native speakers in learning it, further hampering their acquisition of content knowledge through its simultaneous usage as LoI. This could be treated as routine and needed not constitute an oddity considering that it is standard practice in African education to use foreign languages as languages of instruction. The problem with Afrikaans turned out to be entirely political in that it is mired in the racism and politics of exploitation, dehumanization, and domination of the apartheid era. Its presence as language of instruction derived from the politics of white supremacy. The criticism leveled against Stellenbosch University was that it had remained ".... little enclave protecting the interests of the architects of apartheid, and by extension the language of the oppressor, Afrikaans" ${ }^{\prime 30}$. The arguments against Afrikaans did not invoke putative linguistic deficiency for representation or expression of math concepts, or science education, or for technological development; they were entirely political (Kamwangamalu, 2013). The current situation has a precedent. On 16 June 1976, students in Soweto, South Africa, rebelled against the introduction of Afrikaans in black schools as language of instruction. The arguments were political, not based on any disadvantages to knowledge representation or expression associated with the language. The Apartheid regime responded with a crackdown that left more than 175 students dead. The policy did not get implemented because of the political hostility that it ignited, that resulted in the loss of young African lives.

\section{Conclusion}

During a public address at the Chancellor College campus of the University of Malawi, Kamuzu Banda, the first President of Malawi, once humored the academics with the comment that they are so knowledgeable that they have answers to, practically, anything and everything. To make his point, he gave a story of a president of some (fictitious) country who, one day, decided that he should declare war on a neighboring country. When his senior cabinet advisors demanded to know why, he directed them to the academics, who would provide cogent reasons. The story was jocular but it contained relevant points. Politicians make decisions and set the agenda while the bureaucrats, technocrats, scholars, media specialists, public relations officers or propagandists (Herman \& Chomsky, 1998), etc., rationalize and implement them, and therein lies part of the problem. The policies, sometimes, do not take into account the input of the technocrats, scholars, the realities on the ground, etc. The politicians may craft policies based on their estimation of what is conceived as popular to the electorate. With regard to language in education, the policies become a matter of political expediency for the incumbent or "the politicians of the day, and there is very little interface between linguists (who do research) and the politician who makes the decisions" (Edrinne Kayambazinthu, personal communication). The situation effectively reduces to a top-bottom language policy that is dictated by political interests or donor pressure or ideological orientations. Lacking is the input from grass-root realities. Clearly,

\footnotetext{
28 There are parallels that can be drawn with the award of tenders for construction that the Chinese win. One may wonder whether the awards signal a lack of trust in one's own people, perhaps due to past experiences.

29 Retrieved from http://www.bbc.com/news/world-africa-34807291

${ }^{30}$ Retrieved from http://www.bbc.com/news/world-africa-34807291
} 
there is need for bottom-up policies that are informed through the input from objective and thorough surveys of the language situations in the countries, and divergent regions within a country, to determine the possible optimal solutions ${ }^{31}$.

In both Kenya and Malawi, educational reforms that can provide space to indigenous languages and knowledge systems depend, first and foremost, on political will. It has been a perennial criticism of language in education policies in Africa, that there has lacked the political will to effect meaningful changes. The political convenience of retaining foreign languages and knowledge systems to perpetuate the dominance of an elite minority, interwoven with the putative political costs of multilingualism, the fragility of the economic base, the costs associated with the development of the infrastructure, the unavailability of books or teachers, etc., gets invoked to maintain the status quo. In addition, they invoke politically inspired views about the unsuitability or inadequacy of African languages for knowledge representation and expression (where knowledge routinely gets equated with STEM subjects) and as media of instruction. Inevitably, relevant quarters, politically connected individuals, or "well-intentioned" scholars provide the necessary rationalization. This, however, has not ameliorated the chronic stagnation in educational performance where, after half a century of independence, the cultural agency of the UN has to lament that “... a quarter of a billion children worldwide are failing to learn basic reading and math skills in an education crisis that costs governments $\$ 129$ billion annually". The report noted of the problem of education in Africa that, while worldwide 25 per cent of children in poor countries cannot read a sentence, the figure rises to 40 per cent in sub-Saharan Africa ${ }^{32}$.

For meaningful development in Kenya, Malawi, or sub-Saharan Africa in general, it is necessary to realize that knowledge is "... a local commodity designed to satisfy local needs and to solve local problems" (Feyerabend, 1987, p. 28). The knowledge includes, inter alia, introducing the young into life of "the society where they are born and into the physical universe that surrounds the society" (Feyerabend, 1981, p. 163). Education is the program of equipping the individual with that socio-culturally determined knowledge shaped by local contextual parameters. Such indigenous or traditional knowledge includes that of the variety commonly labeled "scientific", acquired and/or, in the ideal case, delivered in the language of the society. The knowledge embodied in "science" that is associated with formal schooling is, itself, the product of specific methodological aspects of inquiry fostered by, and supported within, specific socio-cultural-politico-economic contexts or environments. Education, concerned with imparting knowledge about the world, should incorporate, as a central component, that kind of knowledge, with its exposition in the languages best suited for ease of comprehension. This does not preclude the incorporation of other knowledge systems, or the study and use of other languages. These should get integrated into, but not replace, culturally relevant educational programs. Ngara provides a pertinent proverb, drawn from the cultural wisdom of the Shona of Zimbabwe. It says that Kakova kanozara nemadirirano (The river is flooded by tributaries). Ngara's (2007) comment on this is that it "... implies that, to get a more complete and realistic understanding of the world, we need to value all the available alternative ways of knowing as much as our own" (p. 10). The diffusion of ideas has been crucial to advances in knowledge. Western science and math gained much from the knowledge systems of other societies.

The story of China provides useful lessons. At the time of African independence China did not stand out

\footnotetext{
31 President Kamuzu Banda of Malawi used to state quite openly that he did not or would not agree with the "so-called experts" except when their advice concurred with his views. In other words, experts had to endorse his policies or political agenda 32 Retrieved from https://www.africanewshub.com/news/985928-four-in-10-african-children-cannot-read-a-sentence-new-un-study-finds
} 
as a world power, except for its physical size. The transformation that has occurred, leading to its current political and economic might, derives from the exploitation of local knowledge, local resources, with educational programs that largely exploited the linguistic resources and linguistic heritage of the society. The altered image of Chinese Language, just like that of Afrikaans, does not rest on the alleged language's unique suitability for math, science and technology. Like every other language, it has the latitude to express whatever is humanly conceivable (Katz, 1972). The current positive image of Mandarin derives from China's largesse used as an instrument in the politics of China's extraction of resources. The economic and trade benefits that accrue from China's foreign policy and international aid have served to make Kenya and Malawi and other African countries receptive to Chinese culture and language. In other words, the presence of Chinese Language and culture in African education and social life is a consequence of politics, sustained by economic incentives and investments. Just as the arguments against Afrikaans were political in that the language is mired in the racism and politics of exploitation, dehumanization, and domination of the apartheid era, its presence as language of instruction deriving from the politics of white supremacy, so it is with the incorporation of African knowledge systems in the curricula and, more importantly, the use of African languages as media of instruction. It is the politics of black inferiority, induced by lack of political will, that infuse and inform the choice of language in education in Africa.

\section{References}

Albaugh, E. A. (2014). State-building and multilingual education in Africa. Cambridge: Cambridge University Press.

Babaci-Wilhite, Z. (2015). Local languages as a human right in education. Rotterdam, Netherlands: Sense Publishers.

Babaci-Wilhite, Z. (2016). The use of local languages for effective science literacy as a human right. In Z. Babaci-Wlhite (Ed.), Human rights in language and STEM education (pp. 3-15). Rotterdam, Sense Publishers.

Babaci-Wilhite, Z., Mcleans, A. G., \& Shizhou, L. (2012). Education and language: A human right for sustainable development in Africa. International Review of Education, 58(5), 619-647.

Bamgbose, A. (2011). African languages today: The challenge of and prospects for empowerment under globalization. In E. G. Bokamba et al. (Eds.), Selected proceedings of the 40th Annual Conference on African Linguistics (pp. 1-14). Somerville, MA: Cascadilla Proceedings Project.

Biakolo, E. (2003). Categories of cross-cultural cognition and the African condition. In P. H. Coetzee, \& A. P. J. Roux (Eds.), The African philosophy reader: A text with readings (2nd ed.) (pp. 9-21). New York, NY: Routledge.

Blommaert, J. (2006). Language policy and national identity. In T. Ricento (Ed.), An introduction to language policy: Theory and method (pp. 238-254). Oxford: Blackwell Publishing.

Bokamba, E. G. (2011). Ukolonia in African language policies and practices. In E. G. Bokamba et al. (Eds.), Selected proceedings of the 40th Annual Conference on African Linguistics (pp. 146-167). Somerville, MA: Cascadilla Proceedings Project.

Brock-Utne, B. (2007). Democracy in a multilingual and multicultural society. Keynote lecture at conference on Mother Tongue, Bilingualism and Democracy: Myths, Realities and Consensus. Copenhagen, 28-30 November 2007.

Brock-Utne, B. (2012a). Learning for all of Africa's children-but in whose language? Commonwealth Education Partnerships, $13,147-150$.

Brock-Utne, B. (2012b). Language and inequality: Global challenges to education. Compare: A Journal of Comparative and International Education, 42(5), 773-793.

Bunyi, G. W. (1999). Rethinking the place of African indigenous languages in African education. International Journal of Educational Development, 19, 337-350.

Bunyi, G. W. (2008a). The place of African indigenous knowledge and languages in education for development: The case of Kenya. In S. N. Dlamini (Ed.), New directions in African education: Challenges and possibilities (pp. 15-39). Publisher: University of Calgary Press.

Bunyi, G. W. (2008b). Constructing elites in Kenya: Implications for classroom language practices in Africa. In M. Martin-Jones, A. M. de Mejia, \& N. H. Hornberger (Eds.), Encyclopedia of language and education: Discourse and education (Volume 3) 
(2nd ed.) (pp. 147-157). Springer Science+Business Media LLC.

Cammack, P., Pool, D., \& Tordoff, W. (1988). Third World politics. A comparative introduction. Baltimore, MD: The Johns Hopkins University Press.

Chomsky, N. (1986). Knowledge of language: Its nature, origin, and use. New York: Praeger

Chumbow, B. S. (2013). Mother tongue-based multilingual education: Empirical foundations, implementation strategies and recommendations for new nations. In H. McIlwraith (Ed.), Multilingual education in Africa: Lessons from the Juba Language-in-Education Conference (pp. 37-56). London: British Council.

Connor-Linton, J. (2006). Writing. In R. Fasold, \& J. Connor-Linton (Eds.), An introduction to language and linguistics (pp. 401-432). Cambridge: Cambridge University Press.

Crowder, M. (1962). Senegal and assimilation Senegal: A study in French assimilation policy. London: Oxford University Press for Institute of Race Relations.

Crowder, M. (1964). Indirect rule: French and British style. Africa: Journal of the International African Institute, 34(3), 197-205.

Elliott, F. (2009). Science, metaphoric meaning and indigenous knowledge. Alberta Journal of Educational Research, 55(3), 284-297.

Espositi, M., \& Tse, T. (2015, November 20). What does China's role in Africa say about its growing global footprint? Mail \& Guardian.

Fanon, F. (1967). Black skin, white masks. New York: Grove Press.

Feyerabend, P. (1981). How to defend society against science. In I. Hacking (Ed.), Scientific revolutions: Oxford readings in philosophy (pp. 156-167). Oxford: OUP.

Feyerabend, P. (1987). Farewell to reason. New York: Verso.

Freire, P. (1970, 1998). Pedagogy of the oppressed. (M. B. Ramos, Trans.). New York: Continuum.

Gacheche, K. (2010). Challenges in implementing a mother tongue-based language-in-education policy: Policy and practice in Kenya, University of Leeds. POLIS Journal, 4, 1-45.

Githinji, P. (2008). Ambivalent attitudes: Perception of Sheng and its speakers. Nordic Journal of African Studies, 17(2), 113-136.

Githiora, C. (2002). Sheng: Peer language, Swahili dialect or emerging creole? Journal of African Cultural Studies, 15(2), $159-181$.

Givens, J. R. (2015). A grammar for black education beyond borders: Exploring technologies of schooling in the African diaspora. Race Ethnicity and Education, 19, 1288-1302.

Greer, B., Mukhopadhyay, S., \& Roth, W-M. (2012). Mathematics and politics of knowledge. In S. Mukhopadhyay, \& W-M. Roth (Eds.), Alternative forms of knowing mathematics: Celebrations of diversity of mathematical practices (pp. 9-16). Rotterdam, The Netherlands: SENSE Publishers.

Hailey, F. (1938). An African survey: A study of problems arising in Africa south of the Sahara. London: Oxford University Press. Hale, K. (1974). Navajo linguistics II. Special Lecture Series.

Herman, E. S., \& Chomsky, N. (1988). Manufacturing consent: The political economy of the mass media. New York: Pantheon Books.

Hill, D. D. (1993). Afrocentric movements in education: Examining equity, race and power relations in the public schools. Hastings Constitutional Law Quarterly, 20, 681-724.

Hotep, U. (2003). Decolonizing the African mind: Further analysis and strategy. Kwame Ture Youth Leadership Institute. Retrieved from http://whgbetc.com/ifbm/decolonizing.html

Joseph, J. E. (2006). Language and politics. Edinburgh University Press, Edinburgh Textbooks in Applied Linguistics.

July, R. W. (1992). A history of the African people (4th ed.). Prospect Heights, IL: Waveland Press, Inc.

Kamunyu, M. (2013). Language, gender and educational disparities among pastoralist women in Kenya: An examination of ODL intervention. Maasai Mara University, Kenya.

Kamwangamalu, N. M. (2013). Multilingualism in Southern Africa. In T. K. Bhatia, \& W. C. Ritchie (Eds.), The handbook of bilingualism an multilingualism (2nd ed.) (pp. 791-812). New York: Blackwell Publishing Ltd.

Kamwendo, G. (2015). The straight for English policy in Malawi. In L. M. Miti (Ed.), The language of instruction question in Malawi (pp. 29-40). Cape Town, Center for the Advanced Study of African Societies (CASAS) CASAS Book Series.

Katz, J. J. (1972). Semantic theory. New York: Harper \& Row.

Khejeri, M. (2014). Teachers' attitudes towards the use of mother tongue as a language of instruction in lower primary schools in Hamisi District, Kenya. International Journal of Humanities and Social Science, 4(1), 75-85. 
Kioko, A. N., \& Muthwii, M. J. (2001). The demands of a changing society: English in education in Kenya today. Language, Culture and Curriculum, 14(2), 201-213.

Kishindo, P. J. (1990). An historical survey of spontaneous and planned development of Chichewa. In I. Fodor, \& C. Hagége (Eds.), Language reform (pp. 59-82). Hamburg: Helmut Buske Verlag.

Kishindo, P. J. (1996). Dr. H. Kamuzu Banda's language policy: A study in contradictions. AAP, 48, 55-79.

Kishindo, P. J. (2015). The bird that was not allowed to fly: The case of mother-tongue language policy in Malawi. In L. M. Miti (Ed.), The language of instruction question in Malawi (pp. 9-28). Cape Town, Center for the Advanced Study of African Societies (CASAS) CASAS Book Series 113.

Knagg, J. (2013). Taking and implementing language-in-education decisions: Applying principles to local contexts. In H. McIIwraith (Ed.), Multilingual education in Africa: Lessons from the Juba Language-in-Education Conference (pp. 69-75). London: British Council.

Kwok, P. K. P. (2015). Obstacles of and suggestions to achieving "Learning for All" in Africa: Malawi as a case study. Current Studies in Comparative Education, Science and Technology, 2(1), 32-54

Lee, C. J. (2015). Frantz Fanon: Toward a revolutionary humanism. Athens, OH: Ohio University Press.

Marshall, A. T. (2015). Kiswahili and decolonization: The inter-territorial language committee and successor organizations, 1930-1970 (MA Thesis, American University, Washington DC).

Matiki, A. (1997). The politics of language in Malawi: A preliminary investigation. In R. K. Herbert (Ed.), African linguistics at the crossroads: Papers from Kwaluseni (pp. 521-540). Koln: Rudiger Koppe.

Matiki, A. (2002). Language planning and linguistic exclusion in the legislative process in Malawi. World Congress on Language Policies (pp. 1-17). Barcelona, 16-20 April, 2002,

Mazrui, A. M. (1997). The World Bank, the language question and the future of African education. Race \& Class, 38, 3, 35-48.

Mazrui, A. M., \& Mazrui, A. A. (1996). A tale of two Englishes: The imperial language in post-colonial Kenya and Uganda. In J. A. Fishman, A. W. Conrad, \& A. Rubal-Lopez (Eds.), Post-imperial English: Status change in former British and American colonies, 1940-1990 (pp. 271-301). Publisher: Walter de Gruyter.

Mazrui, A. A., \& Mazrui, A. M. (1998). The power of Babel: Language \& governance in the African experience. Chicago: The University of Chicago Press.

Mchombo, S. (1998a). Democratization in Malawi: Its roots and prospects. In J-G. Gros (Ed.), .Democratization in late twentieth-century Africa: Coping with uncertainty (pp. 21-40). Westport, CT: Greenwood Press.

Mchombo, S. (1998b). National identity, democracy, and the politics of language in Malawi and Tanzania. The Journal of African Policy Studies, 4(1), 33-46.

Mchombo, S. (2000). Chichewa. In J. Garry, \& C. Rubino (Eds.), Facts about the world's languages: An encyclopedia of the world's major languages, past and present (pp. 131-133). New York and Dublin: The H.W. Wilson Company.

Mchombo, S. (2009). Nyanja. In K. Brown, \& S. Ogilvie (Eds.), Concise encyclopedia of languages of the world (pp. 791-797). Oxford: Elsevier Ltd.

Mchombo, S. (2014). Language and the contextualization of education in Africa. Russian-American Education Forum: An Online Journal, 6(3). Retrieved from http://www.rus-ameeduforum.com/content/en/?task=art\&article=1001088\&iid=20

Mchombo, S. (2016). Language, scientific knowledge, and the "context of learning" in African education. In Z. Babaci-Wlhite (Ed.), Human rights in language and STEM education (pp. 129-150). Rotterdam, Sense Publishers.

Michalopoulos, S., \& Papaioannou, E. (2013). The long-run effects of the scramble for Africa. Centre for Economic Policy Research. Retrieved December 2, 2014, from http://www.voxeu.org/article/long-run-effects-scramble-africa

Moto, F. (2009). Language, power \& society. Pretoria: University of South Africa Press.

Moyo, D. (2012). Winner take all: China's race for resources and what it means for us. London: Penguin Books.

Mtenje, A. (2013). Developing a language policy in an African country: Lessons from the Malawi experience. In H. McIIwraith (Ed.), Multilingual education in Africa: Lessons from the Juba Language-in-Education Conference (pp. 95-102). London, UK: British Council.

Mugane, J. M. (2006). Necrolinguistics: The linguistically stranded. In J. Mugane et al. (Eds.), Selected proceedings of the 35th Annual Conference on African Linguistics (pp. 10-21). Somerville, MA: Cascadilla Proceedings Project.

Mugane, J. M. (2015). The story of Swahili. Athens, OH: Ohio University Press.

Muthwii, M. J. (2002). Language policy and practices in education in Kenya and Uganda. Nairobi: Phoenix Publishers.

Muthwii, M. J. (2004). Language of instruction: A qualitative analysis of the perceptions of parents, pupils and teachers among the Kalenjin in Kenya. Language, Culture and Curriculum [online], 17(1), 15-32. Retrieved June 17, 2010, from 
http://dx.doi.org/10.1080/07908310408666679

Muthwii, M. J. (2007). Language planning and policy in Kenya: Living with unresolved paradoxes. In A. Liddicoat (Ed.), Language planning and policy: Issues in language planning and literacy (pp. 46-62). Clevedon: Multilingual Matters.

Nasir, N. S., \& Hand, V. M. (2006). Exploring sociocultural perspectives on race, culture, and learning. Review of Educational Research, 76(4), 449-475.

Neke, S. M. (2003). English in Tanzania: An anatomy of hegemony (Doctoral dissertation, Universiteit Ghent, Academiejaar 2002-2003).

Ngara, C. (2007). African ways of knowing and pedagogy revisited. Journal of Contemporary Issues in Education, 22(2), 7-20.

Ngom, F. (2010). Ajami scripts in the Senegalese speech community. Journal of Arabic and Islamic Studies, 10, 1-23.

Ngonyani, D. (1997). The failure of language policy in Tanzanian schools. Social Education, 61(7), 412-418.

Ngugi, W. T. (1986). Decolonizing the mind: The politics of language in African literature. Nairobi: East African Educational Publishers.

Nienu, V. (2015). Naga cultural milieu: An adaptation to mountain ecosystem. San Francisco, CA: Dorylus Publishing Group (DPG).

Nkosi, B. (2015). Like it or not, SA schools set to teach Mandarin. Retrieved August 12, 2015, from https://mg.co.za/author/bongani-nkosi

Nobles, W. (1986). African psychology: Toward its reclamation, revitalization and re-ascension. Oakland, CA: Black Family Institute.

Nurse, D., \& Hinnebusch, T. (1993). Swahili and Sabaki: A linguistic history. Berkeley, CA: University of California Press .

Obanya, P. (1999). Popular fallacies on the use of African languages in education. Social Dynamics (Special Issue: Language and Development in Africa), 25(1), 81-100.

Omi, M., \& Winant, H. (1994). Racial formation in the United States: From the 1960s to the 1990s (2nd ed.). New York: Routledge.

Othieno, J. (2014). Our vernacular languages are the best method to teach our children effectively. Retrieved from http://mobile.nation.co.ke/blogs/Our-vernacular-languages-are-the-b...od-to-teach/-/1949942/2199116/-/format/xhtml/-/db3p x1/-/index.html

Pennycook, A. (1994). The cultural politics of English as an international language. Harlow, Essex, UK: Longman Group Limited.

Phillipson, R. (1992). Linguistic imperialism. Oxford: Oxford University Press.

Phillipson, R. (2014). English, the lingua nullius of global hegemony. From Conference on the Politics of Multilingualism: Linguistic Governance, Globalization and Europeanization, University of Geneva, 19-20 June 2014.

Prah, K. (2013). No country can make progress on the basis of a borrowed language. Retrieved from http://ela-newsportal.com/no-country-can-make-progress-on-the-basis-of-a-borrowed-language/

Price, T. (1940). Nyanja linguistic problems. Africa, 13, 125-137.

Republic of Kenya. (1964). Kenya education commission report. Nairobi: Government Printers.

Republic of Kenya. (1976). Report of the national committee on educational objectives and policies. Nairobi: Government Printers.

Rugemalira, J. M., Rubagumya, C. M., Kapinga, M. K., Lwaitama, A, F., \& Tetlow, J. G. (1990). Reflections on recent developments in language policy in Tanzania. In C. M. Rubagumya (Ed.), Language in education in Africa: A Tanzanian perspective (pp. 25-35). Clevedon, England: Multilingual Matters Ltd.

Shizha, E. (2012). Reclaiming and re-visioning indigenous voices: The case of the language of instruction in science education in Zimbabwean primary schools. Literacy Information and Computer Education Journal (LICEJ) (Special Issue), 1(1), $785-793$.

Sibomana, E. (2015). Post-colonial language-in-education policies in Africa: The case of Kenya. Rwandan Journal of Education, $3(1), 37-51$.

Silk, J. (1990). Traditional culture and the prospect for human rights in Africa. In A. A. An-Naim, \& F. M. Deng (Eds.), Human rights in Africa: Cross-cultural perspectives (pp. 290-328). Washington, DC: The Brookings Institution.

Simango, S. R. (2015). Learning English or learning in English: Some thoughts on the language question in the Malawian classroom. In L. M. Miti (Ed.), The language of instruction question in Malawi (pp. 41-60). Cape Town, Center for the Advanced Study of African Societies (CASAS) CASAS Book Series 113.

UNESCO. (1953). The use of vernacular languages in education (Monographs on Fundamental Education). Unesco, Paris.

Ungar, S. J. (1986). Africa: The people and the politics of an emergent continent. New York: Simon \& Schuster, Inc. 
Watkins, M. H. (1937). A grammar of Chichewa: A bantu language of British Central Africa. Publisher: Linguistic Society of America.

Wigglesworth, G., \& Simpson, J. (2008). The language learning environment of preschool children in indigenous communities. In S. May (Ed.), Critical multiculturalism: Rethinking multicultural and antiracist education (pp. 13-29). London: Falmer Press.

Williams, E. (2011). Language policy, politics and development in Africa. In H. Coleman (Ed.), Dreams and realities: Developing countries and the English language (pp. 2-20). London: The British Council.

Wiseman, J. A. (1990). Democracy in black Africa: Survival and revival. New York, NY: Paragon House Publishers.

Wolff, H. E. (2006). Background and history_Language politics and planning in Africa. In H. Alidou et al. (Eds.), Optimizing learning, education and publishing in Africa: The language factor-A Stock-taking research on mother tongue and bilingual education in sub-Saharan Africa (pp. 49-102). Paris, France, Association for the Development of Education in Africa (ADEA).

Young, C. T. (1949). A review of a practical approach to Chinyanja with English-Nyanja vocabulary by T. D. Thompson. Africa 19, 253-254.

Zeleza, P. T. (1997). Manufacturing African studies and crises. Dakar, Senegal: CODESRIA. 